\title{
WATER REQUIREMENTS AND WATER USE EFFICIENCY OF CARROT UNDER DRIP IRRIGATION IN A HAPLOXERAND SOIL
}

\author{
C. Quezada $^{1 *}$, S. Fischer ${ }^{1}$, J. Campos ${ }^{1}$, and D. Ardiles ${ }^{1}$ \\ ${ }^{1}$ Facultad de Agronomía, Universidad de Concepción, Casilla 537, Chillán, Chile. \\ *Corresponding author: cequezad@udec.cl
}

\begin{abstract}
Water management efficiency is a key issue for sustainable agriculture development, since it is necessary to get a higher biomass production per unit of applied water. This study aimed to determine both water requirements and water use efficiency (WUE) and their effect on yield and quality parameters in carrots (Daucus carota L.), during the 2006 - 2007 growing season in Chillán, Chile $\left(36^{\circ} 35^{\prime} 43.2^{\prime \prime} \mathrm{S}, 7^{\circ} 04^{\prime} 39^{\prime \prime} \mathrm{W}, 140 \mathrm{~m}\right.$ altitude). The water treatments applied were $25,50,75,100$ and $125 \%$ pan evaporation $\left(\mathrm{E}_{\mathrm{pan}}\right)$ in a Haploxerand soil under drip irrigation. The results showed that the highest crop yield was obtained with $100 \% \mathrm{E}_{\mathrm{pan}}$ treatment. However, the highest WUE was found in the $75 \% \mathrm{E}_{\mathrm{pan}}$ treatment equivalent to $3864 \mathrm{~m}^{3} \mathrm{ha}^{-1}$, which is the recommended water application level in irrigation scheduling. Regarding carrot crop yield and quality parameters, statistical differences between the different water treatments were not significant, but the increase of applied water $\left(125 \% \mathrm{E}_{\mathrm{pan}}\right)$ reduced plant density and root length. This relationship between yield and applied water will allow to improve the management of water resources under water scarcity.
\end{abstract}

Keywords: Water content, Roots quality, Water stress, Andisols.

\section{INTRODUCTION}

Scarcity of water resources is a worldwide issue due to their increasing demand, as a result of world's growing population and social-economic development (Zapata y Segura, 1995). The pressure on water resources is expected to increase as the requirements for food production and industrial needs go up in parallel with the country's rapidly growing population (Webber et al., 2006). Water resources are limited worldwide and there is an urgent need to identify and adopt efficient irrigation management strategies since irrigation of agricultural lands accounts for over $85 \%$ of worldwide water usage (Zegbe et al., 2006).
Sprinkler and drip irrigation systems can be used to decrease agricultural water demand. Water savings can be achieved either by decreasing the frequency of irrigation events or by a systematic reduction of water inputs (Darwish et al., 2006). Richards et al.(2002) indicate that crop water use efficiency (WUE) can be increased either by enhancing crop transpiration or by plant breeding to produce greater biomass $\left(\mathrm{CO}_{2}\right.$ assimilation) and yield per unit of water used.

Climate change poses significant challenges to agriculture due to increased temperatures, droughts and water scarcity, 
but it also provides opportunities to improve crop yields in arid and semiarid zones. Yield of water-limited crops is determined by crop water use and WUE, both of which can be affected by the increase in atmospheric carbon dioxide $\left(\mathrm{CO}_{2}\right)$ and temperature. At leaf level, the increase in transpiration efficiency may result both from an increase in photosynthetic rate and a decrease in stomatal conductance (Wayne, 2002).

WUE can be maximized by applying deficit irrigation, irrigation technology and irrigation scheduling as well as by improving agricultural practices that can result in the increase of crop yields. Drip irrigation is the response to pressure on limited fresh-water resources and plays an important role in the increase of WUE. Nevertheless, there is still limited information on how to use it on conventional crops. Hassanli et al. (2010) found that WUE increased from $4.15 \mathrm{~kg}$ $\mathrm{m}^{-3}$ with furrow irrigation to $8.2 \mathrm{~kg} \mathrm{~m}^{-3}$ with drip irrigation in a sugar beet crop. WUE has remained as a research topic of interest to plant, soil and irrigation specialists due to the fact that water shortage for agriculture has generated a strong need to design strategies aimed at improving WUE (Behboudian and Sing, 2001). In addition, it can be used as a tool of plant management to improve crop yield and product quality.

Water use efficiency (WUE) is generally used to express the ratio of total dry matter production to evapotranspiration and it is influenced by a variety of factors, such as crop type, atmospheric environment, cultivation practices and soil conditions (Liu et al., 2002). Given the climate characteristics of Chile, droughts occur with frequency and these affect water availability in irrigated zones, resulting in a high risk for crop production (Sellés et al., 2003). It is also noteworthy that $84.5 \%$ of the consumptive water rights are used in agricultural land irrigation (Novoa, 2004). Therefore, it is necessary to increase WUE, decreasing the applied water volume without affecting crop yield, especially in water-scarce regions (Bebhoudian and Singh, 2002).

Chile presents a great variety of soils. The Central Zone of the country presents a wide range of soil types from different origins and characteristics, predominating alluvial soils and those derived from volcanic ashes (Honorato, 2000). Carrot is considered as an economically important crop for the country, with a seeded area of 3819.76 ha in the season 20062007. This crop is mainly produced in the Bío-Bío Region (999.67 ha), the Metropolitan Area (915.70 ha) and the Valparaiso (822.70 ha) Region (INE 2007). Carrots are cultivated preferably in deep, loam textured, not stony, well drained soils (Giaconi and Escaff, 1993).

Water requirements range from 6000 and $9000 \mathrm{~m}^{3} \mathrm{ha}^{-1}$ with an average pan evaporation of 6 to $7 \mathrm{~mm} \mathrm{~d}^{-1}$, depending mainly on the crop period, which lasts between 100 and 140 days (Villeneuve and Leteinturier, 1992). A study carried out on a carrot crop showed higher root production, total dry matter and WUE with a water application level of $100 \%$ $\mathrm{E}_{\mathrm{pan}}$ (Prabhakar et al., 1991). Moreover, Gibberd et al. (2003) studied water application in a carrot crop cultivated in sandy soils and determined that a higher marketable carrot yield is obtained with water application level of $151 \% \mathrm{E}_{\mathrm{pan}}$. However, there is little information available in our country regarding carrot irrigation management with high efficiency systems. Therefore, this study aimed at determining water requirements and WUE, by applying different water application levels on a carrot crop under drip irrigation and evaluating their effects on yield and quality parameters in Haploxerand soils. 


\section{MATERIALS AND METHODS}

\section{Experimental site}

This study was performed at El Nogal Experimental Station of the University of Concepcion in Chillán, Chile $\left(36^{\circ} 35^{\prime}\right.$ 43.2 " S, 72 $044^{\circ} 39^{\prime \prime} \mathrm{W}, 144 \mathrm{~m}$ above sea level) during 2006-2007 growing season. This area presents a Mediterranean climate, with an annual rainfall of about $1000 \mathrm{~mm}$ per year, concentrated between May and August, with a potential evapotranspiration of around $1200 \mathrm{~mm}$. Annual mean temperature is $13.6^{\circ} \mathrm{C}$, with an average temperature of $8.0^{\circ} \mathrm{C}$ in the coldest month (July) and $19.7^{\circ} \mathrm{C}$ in the hottest month (January). Annual mean relative humidity is $71.3 \%$ and the frostfree period is 5 to 6 months. Soil is classified as medial, amorphic, thermic Humic Haploxerands, derived from volcanic ashes, moderately deep, loamy textured, with an average bulk density of $1.18 \mathrm{~g} \mathrm{~cm}^{-3}$, and with good drainage (Stolpe, 2006). Soil water content (0-30 $\mathrm{cm}$ depth) varied between $45.8 \%$ BDW (basis dry weight) at field capacity (FC) and $31.3 \% \mathrm{BDW}$ at permanent wilting point (PWP). Threshold level (TL) corresponds to $50 \%$ of plant available water or difference between values for FC and PWP. The carrot crop was sown manually in September. The used variety was Abaco and seeds were sown at rate of $1-2$ seeds $5 \mathrm{~cm}^{-1}\left(1.7\right.$ a $\left.2.5 \mathrm{~kg} \mathrm{ha}^{-1}\right)$. Prior to sowing, soil was fertilized with concentrated superphosphate $24 \mathrm{~kg} \mathrm{ha}^{-1}$, urea $24 \mathrm{~kg} \mathrm{ha}^{-1}$ and potassium muriate 50 $\mathrm{kg} \mathrm{ha}^{-1}$. Foliar nitrogen was applied at a rate of $30 \mathrm{~kg} \mathrm{~N} \mathrm{ha}^{-1}$ in November.

\section{Experimental design}

The experiment was set up in a randomized block design with five treatments and four replicates. The plot size was $5 \mathrm{~m}$ x $0.7 \mathrm{~m}$. Each plot consisted of eight rows. Water treatments were set as a percentage of $\mathrm{E}_{\mathrm{pan}}$ : values of $25 \%$, $50,75,100$ and $125 \%$ for $2007-2008$ period, according to data provided by the Agrometeorological Station of University of Concepción in Chillán. Crop evapotranspiration was determined as follows:

$\mathrm{ET}_{\mathrm{c}}=\mathrm{E}_{\mathrm{pan}} * \mathrm{~K}_{\mathrm{pan}} * \mathrm{~K}_{\mathrm{c}}$

where: $\mathrm{ET}_{\mathrm{c}}=$ crop evapotranspiration; $\mathrm{E}_{\mathrm{pan}}=$ pan evaporation $\left.(\mathrm{mm} \mathrm{day})^{-1}\right) ; \mathrm{K}_{\mathrm{c}}=$ plant coefficient; $\mathrm{K}_{\mathrm{pan}}=$ pan coefficient (0.75). The used $K_{c}$ values were initial (0.7); mid-season (1.05) and late season (0.95) (FAO, 2006).

Water was applied by drip irrigation, using tape Queen Gil (Bulgaria) with emitters spaced $10 \mathrm{~cm}$ apart, each delivering $4 \mathrm{~L} \mathrm{~h}^{-1} \mathrm{~m}^{-1}$, at a pressure of 10 water meter column pumped from a 5 $\mathrm{m}$ deep well with Pedrollo (Italy) $\mathrm{CPm}$ 158-E of $1 \mathrm{HP}$.

\section{Soil water measurements}

Soil water tension was measured in each treatment on a weekly basis and after each irrigation, using tensiometers Irrometer at $30 \mathrm{~cm}$ deep. In addition, the volumetric soil water content was measured by dielectric sensor TDR, Delta Devices model Profile Prob-PR2 (England) at 30 $\mathrm{cm}$ deep. The calibration curve was performed during the trial period, obtaining the following regression equation $\left(\mathrm{R}^{2}=0.8597\right)$

$\theta=0.0991 \times-2.1002$

where: $\theta=$ volumetric water content $(\%) ; \mathrm{x}=$ volumetric water content dielectric sensor $\left(\mathrm{m}^{3} \mathrm{~m}^{-3}\right)$

\section{Crop yield parameters}

Crop yield parameters were measured in three dates during the crop period 
(December 28, 2006 and January 15 and 25, 2007). Measurements were carried out in 5 plant samples per replicate and treatment in a $50 \mathrm{~cm} \times 50 \mathrm{~cm}$ square, and the following determinations were made: (a) plant number, (b) marketable yield, (c) biomass accumulation, and (d) root basal diameter. Fresh weight and dry weight of roots and foliage was also measured in order to determine biomass accumulation. Foliage samples were dried at $60^{\circ} \mathrm{C}$ for 48 hours to foliage, and root samples were dried at $60^{\circ} \mathrm{C}$ for 96 hours in SL Shel Lab ventilation oven, model 1370 FX (United States).

WUE was determined by the relationship between $\mathrm{kg}$ fresh matter and $\mathrm{m}^{3}$ applied water. In addition, the harvest index (HI) or relationship between cropping biomass and total biomass was also determined.

\section{Root quality parameters}

Soluble solid concentration ( ${ }^{\circ}$ Brix) of roots was determined at physiological maturity, using a KRUSS refractometer(Germany) model HRT-32. Measurements were also made at harvest time by evaluating the length of the main root.

\section{Statistical analysis}

Data were analyzed using analysis of variance (ANOVA). Comparisons between averaged values from the different treatments were made by the Duncan's test at 0.05 probability significance level (Infostat, 2004). Plant density data were subjected to nonparametric ANOVA by Kruskal-Wallis ( $p$ $\leq$ 0.05). The conversion of data to percentage was made by the relationship $(\mathrm{x}+0.5)^{1 / 2}$ to adjust them to normal distribution (Steel and Torrie, 1992).

\section{RESULTS AND DISCUSSION}

\section{Applied water volume}

The applied water volumes were 2379 $\mathrm{m}^{3}$ for $25 \%$; $3122 \mathrm{~m}^{3}$ for $50 \%$; $3864 \mathrm{~m}^{3}$ for $75 \%$; $4607 \mathrm{~m}^{3}$ for $100 \%$, and $5349 \mathrm{~m}^{3}$ for $125 \% \mathrm{E}_{\mathrm{pan}}$ (Table 1), including rainfall from November 9, 2006 to January 24, 2007.

Table 1. Water requirements and water use efficiency in carrot with different water treatments under drip irrigation in a Haploxerand soil. Columns with different letters differ significantly, Duncan's test $(p \leq 0.05)$.

\begin{tabular}{|c|c|c|c|c|}
\hline Treatments & $\begin{array}{c}\text { Yield } \\
\left(\mathrm{kg} \mathrm{ha}^{-1}\right)\end{array}$ & $\begin{array}{l}\text { Applied water } \\
\qquad\left(\mathrm{m}^{3} \mathbf{h a}^{-1}\right)\end{array}$ & $\begin{array}{c}\text { WUE } \\
\left(\mathrm{kg} \mathrm{m}^{-3}\right)\end{array}$ & $\begin{array}{c}\Delta \mathrm{Y} / \Delta W \\
\left(\mathrm{~kg} \mathrm{~m}^{-3}\right)\end{array}$ \\
\hline $25 \% \mathrm{~Eb}$ & 67,434 a & 2379 & $28.3 \mathrm{a}$ & - \\
\hline $50 \% \mathrm{~Eb}$ & $80,490 \mathrm{ab}$ & 3121 & $25.8 \mathrm{a}$ & 17.58 \\
\hline $75 \% \mathrm{~Eb}$ & $94,891 \mathrm{~b}$ & 3864 & $24.6 \mathrm{a}$ & 19.40 \\
\hline $100 \% \mathrm{~Eb}$ & $103,632 \mathrm{~b}$ & 4606 & $21.4 \mathrm{a}$ & 11.77 \\
\hline $125 \% \mathrm{~Eb}$ & $98,456 \mathrm{~b}$ & 5349 & $19.4 \mathrm{a}$ & -6.97 \\
\hline
\end{tabular}

$\mathrm{WUE}=$ Water use efficiency; $\Delta \mathrm{Y} / \Delta \mathrm{W}=$ Marginal yield $/$ Marginal water applied 
Spring rainfall reached $90.99 \mathrm{~mm}$ prior irrigation, and during the period of plant growth, which allowed a good level of soil moisture. The total rainfall was $163.68 \mathrm{~mm}$ (Figure 1). The total pan evaporation was $537.79 \mathrm{~mm}$, with an average of $5.54 \mathrm{~mm} \mathrm{~d}^{-1}$ during crop growing season. In contrast, Galeano
(2003) determined that with a water application level of $7 \mathrm{~mm}$ day ${ }^{-1}$ and adding the season rainfall, applied water was $9261 \mathrm{~m}^{3} \mathrm{ha}^{-1}$ with drip irrigation in carrots. These differences can be explained by the number of irrigations, level of water applications and soil water retention capacity.

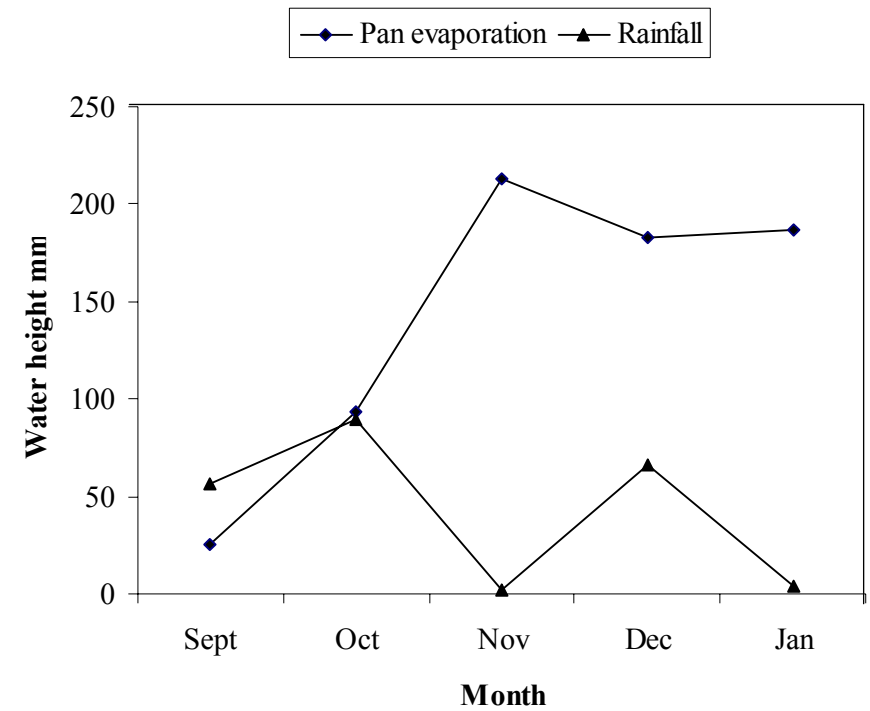

Figure 1. Pan evaporation and rainfall during the 2006-2007 growing season in Chillán, Chile.

\section{Soil water tension}

Soil water tension (Figure 2) shows an increase in 25 and $50 \% \mathrm{E}_{\text {pan }}$ treatments due to a rapid and constant loss of soil water content, as a result of a low water application, with tensions between 60 and $70 \mathrm{cb}$. On the other hand, soil presents higher water availability and tensions between 15 to $20 \mathrm{cb}$ with the $100 \%$ and $125 \% \mathrm{E}_{\text {pan }}$ treatments, during the whole growing period of carrots. Therefore, a better development and higher crop yield was obtained, the same as with $75 \% \mathrm{E}_{\mathrm{pan}}$, where tension ranged between 15 and $50 \mathrm{cb}$. These results agree with the findings of Thompson et al. (2004) who determined that the highest yields in vegetables are obtained with tensions between 15 and $45 \mathrm{cb}$. In this study, critical tensions varied between 40 and $50 \mathrm{cb}$ and between 15 and $20 \mathrm{cb}$, demonstrating that the energy status of soil water is a good indicator of scheduling irrigation in high frequency systems (Taylor et al., 2004). 


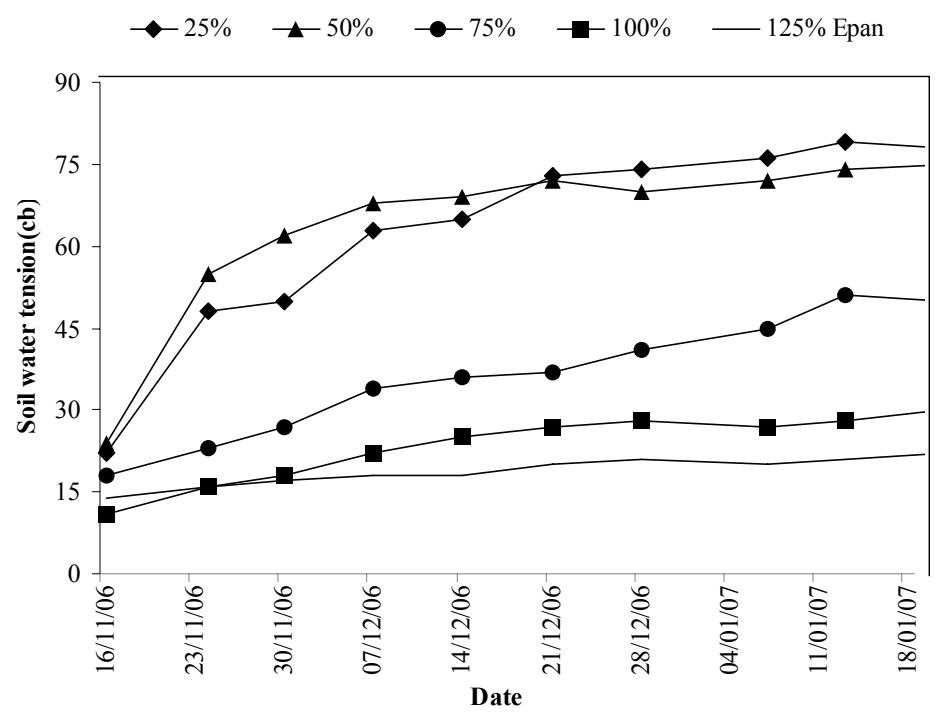

Figure 2. Soil water tension (cb) under the different water treatments measured at 30 $\mathrm{cm}$ deep during the study period in a Haploxerand soil.

\section{Volumetric water content}

The volumetric water content (Figure 3) measured at $30 \mathrm{~cm}$ of soil depth shows that $\mathrm{E}_{\mathrm{pan}}$ treatments the soil water remained during all the season close to $\mathrm{FC}$ in the $100 \%$ and $125 \%$. With $75 \% \mathrm{E}$ pan, a constant loss of soil water content is observed, coming under the threshold level (TL), while with $25 \%$ and $50 \% \mathrm{E}$ pan the level of soil water content decreased rapidly under the TL, reaching levels close to the PWP.

\section{Crop yield parameters}

The results obtained in yield parameters are similar to the findings reported by Gray and Benjamin (1994) who explained that the variation in root weight at harvest can be influenced by plant size at emergence and by the degree of competition between plants. The water treatments did not show significant effects on plant density, root size and discarded roots (quality loss for cracking, deformity, insect damage or diseases). The highest yields were obtained with 75 and $100 \%$ $\mathrm{E}_{\mathrm{pan}}$, probably due to a low density (Table 2) and roots of greater size. The $125 \%$ $\mathrm{E}_{\mathrm{pan}}$ treatment showed lower plant density and smaller root size due to the fact that water excess in the soil decreases the oxygen diffusion rate in the root zone (Wan and Kang, 2006) affecting crop yield. However, these results presented no statistically significant differences $(p>0.05) \quad$ in discarded roots, but there was a significant effect on the total marketable yield of carrot roots (Figure 4). The analysis of the effect of the water treatments on dry weight of roots and foliage ( Figure 5) demonstrated that the highest increases were obtained with $100 \%$ and $125 \% \mathrm{E}_{\text {pan }}$, but with no statistically significant differences $(p \leq$ 0.05 ) were found between the treatments during the season. The curve of fresh weight (data not shown) presented the same shape as the dry weight curve. 


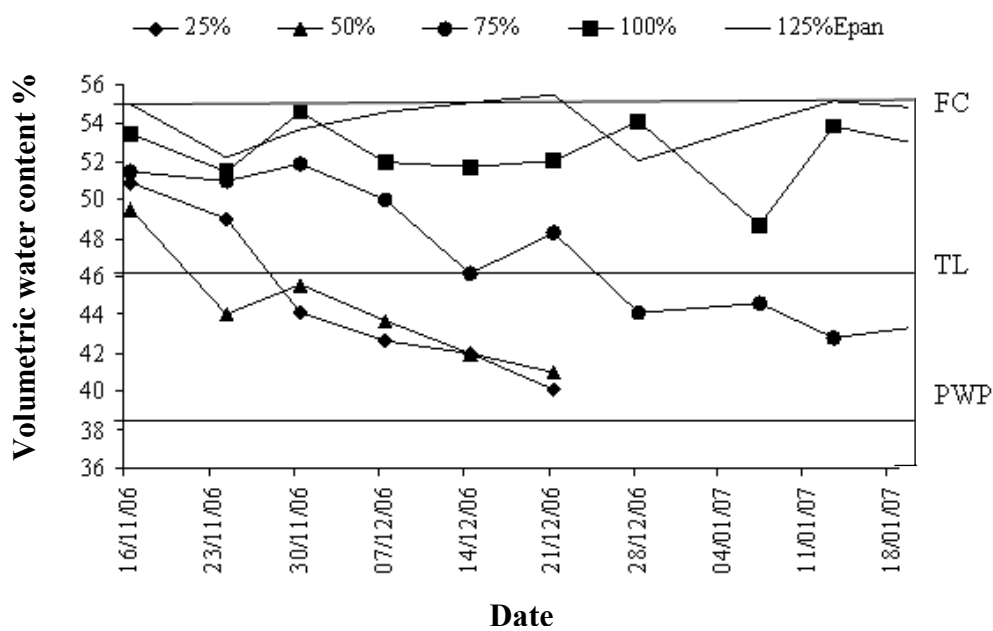

Figure 3. Volumetric water content under different water treatments measured at $30 \mathrm{~cm}$ deep during the study period in a Haploxerand soil. FC: field capacity, TL: threshold level; PWP: permanent wilting point.

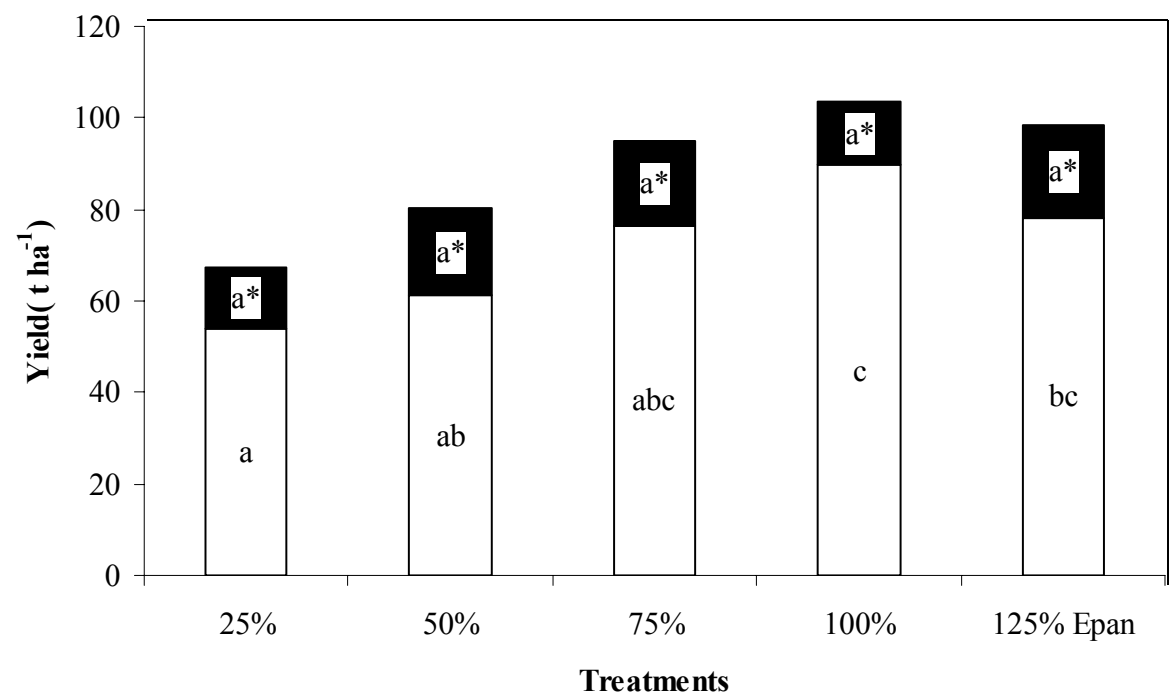

$\square$ Marketable $\square$ Discarded

Figure 4. Total, marketable and discarded root yield $\left(\mathrm{t} \mathrm{ha}^{-1}\right)$ of different water treatments in carrots under drip irrigation in a Haploxerand soil. Columns with different letters differ significantly, Duncan's test $(p \leq 0.05)$. Capital letters refer to total yield, lowercase letters refer to marketable yield and lowercase letters with asterisk refer to discarded yield. 

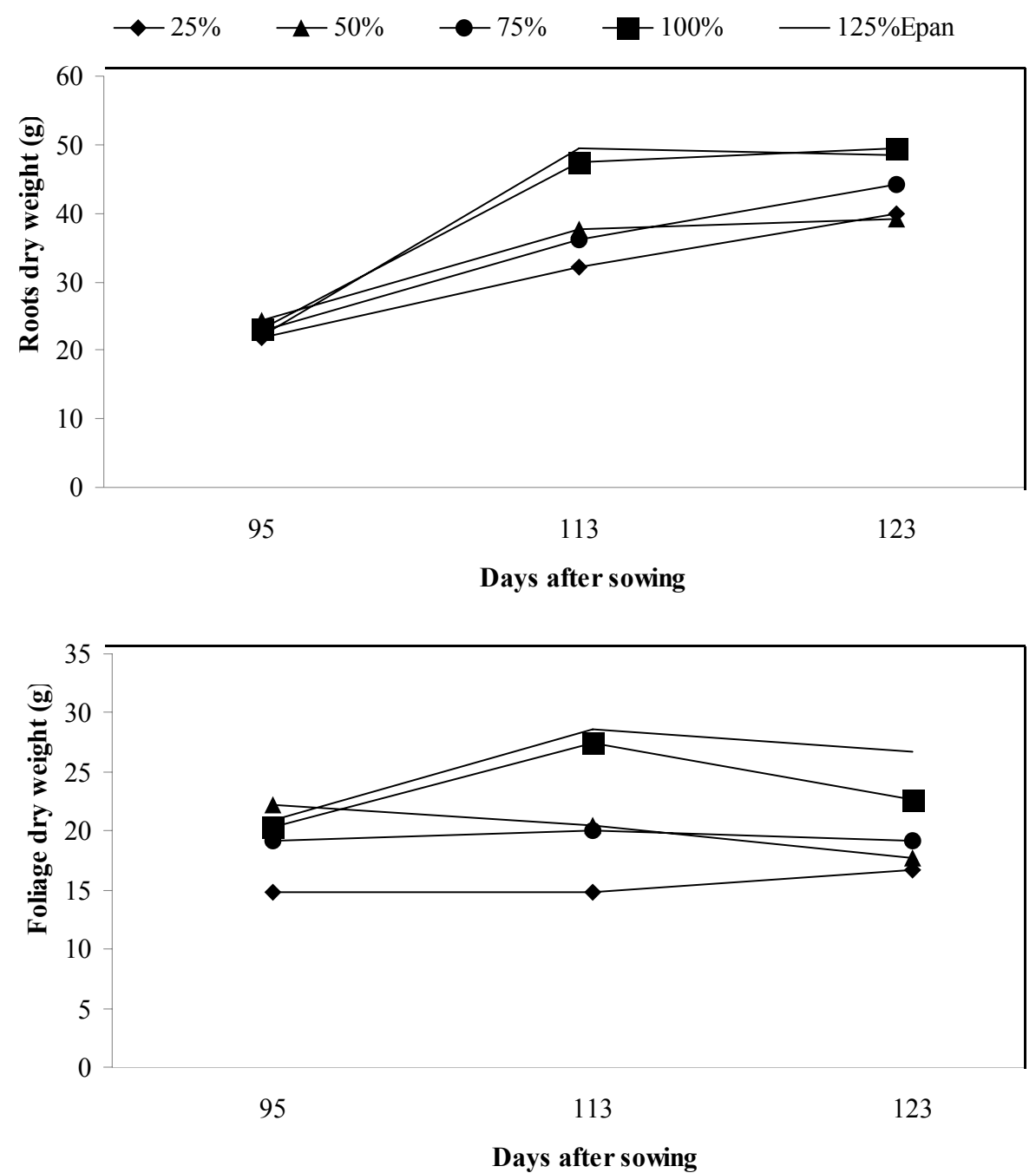

Figure 5. Root and foliage dry weight (g) of carrot in the different water treatments measured at 95, 113 and 123 days after sowing, in a Haploxerands soil.

The treatments with lower applications of water showed a constant growth, probably because the root is less sensitive to water stress than the aerial part of the plant. This could be explained by a higher activity of xiloglucan endotransglicosilasa enzyme (XET), which decreases the tension of the molecules of hemicellulose at low water potential, and it allows root growth (Reigosa et at., 2003). Moreover,
Westerveld et al. (2006) determined that dry matter (DM) accumulation in the roots was generally linear after 53 days sowing (DAS) on the organic soil. Only 5 $\%$ of DM accumulation occurred before this period.

In relation to foliage, the highest values in fresh and dry weight were obtained with the $100 \%$ and $125 \% \mathrm{E}_{\mathrm{pan}}$ treatments at $113 \mathrm{DAS}$, due to the fact 
that a higher water application allowed an optimum transpiration, hence, a high growth of the aerial part of the plant. In the rest of the treatments the effect of water deficit decreased the photosynthetic capacity (assimilation of $\mathrm{CO}^{2}$ ), resulting in a decrease of the leaf stomatal conductance due to stomatal closure and decrease of transpiration, as it has been found in other plants (Sato et al., 2006). Statistical differences $(p \leq 0.05)$ were not significant, except for fresh weight of the foliage at 113 DAS. Westerveld et al. (2006) found that DM accumulation in the foliage was higher than in the roots before 60 DDS and that the peak DM content occurred between 115 and 135 DDS. Then, it gradually decreased on both organic and mineral soil.
The harvest index did not present significant differences between treatments $(p \leq 0.05)$. However, a high harvest index was obtained with the $25 \% \mathrm{E}_{\mathrm{pan}}$ treatment when compared to the rest of the treatments, probably because of the scarce foliage produced (Table 2, due to water stress to which it was submitted. This may be the result of an increase of net synthesis of absicic acid (ABA), that causes the stomatal closure and decreases photosynthesis, as it has been reported in other plants (AzcónBieto and Talón, 2000). Results obtained by Klocker (1997) and Ebner (1995) differ from these results. These authors reported harvest indices around $80 \%$ under rainfed conditions, indicating that plants had a lower foliage development.

Table 2. Plant density, harvest index, soluble solids and root length of carrots with different water treatments under drip irrigation in a Haploxerand soil.

\begin{tabular}{lcccc}
\hline Treatments & $\begin{array}{c}\text { Plant density } \\
\left(\mathbf{1 0}^{\mathbf{3}} \mathbf{h a}^{-\mathbf{1}}\right)\end{array}$ & $\begin{array}{c}\text { Harvest index } \\
\mathbf{( \% )}\end{array}$ & $\begin{array}{c}\text { Soluble solids } \\
\left.\mathbf{(}^{\mathbf{0}} \mathbf{B r i x}\right)\end{array}$ & $\begin{array}{c}\text { Root length } \\
(\mathbf{c m})\end{array}$ \\
\hline $25 \% \mathrm{E}_{\mathrm{pan}}$ & 1410 & 72 & 6.9 & 10.8 \\
$50 \% \mathrm{E}_{\mathrm{pan}}$ & 1520 & 68 & 6.5 & 10.7 \\
$75 \% \mathrm{E}_{\mathrm{pan}}$ & 1510 & 70 & 6.4 & 10.6 \\
$100 \% \mathrm{E}_{\mathrm{pan}}$ & 1400 & 67 & 5.8 & 11.1 \\
$125 \% \mathrm{E}_{\mathrm{pan}}$ & 1300 & 63 & 6.0 & 10.2 \\
Significance & $\mathrm{ns}^{*}$ & $\mathrm{~ns}^{* *}$ & $\mathrm{~ns}^{* *}$ & $\mathrm{~ns}^{* * *}$ \\
\hline
\end{tabular}

$(*)$ Kruskal-Wallis test; $(* *)$ Duncan's test, ns: no significant.

\section{Root quality parameters}

The concentration of soluble solids (Table 2) showed no significant differences in any of the treatments, even though a higher value in degrees ${ }^{\circ}$ Brix (6.9) was obtained with the $25 \% \mathrm{E}_{\mathrm{pan}}$ treatment, when compared with the 100 and $125 \% \mathrm{E}_{\text {pan }}$ ( ${ }^{\circ}$ Brix about 6.0 ). In order to support the potential gradient required for water absorption in soils under water stress, the plant decreases the osmotic 
potential by increasing the levels of organic solutes (Azcón-Bieto and Talón, 2000). The soluble solid concentration obtained in this study is in accordance with data reported by Carlton and Peterson (1963), who obtained a range from 4.5 to $9 \%$ of soluble solids with different carrot cultivars.

Environmental growth conditions affect directly the quality and the production of carrots, while plant density has more influence on yield parameters than in the internal root quality (Evers et al., 1997). Root length (Table 2) presented no significant differences $(p \leq$ 0.05 ) between the treatments of water applications. The $100 \% \mathrm{E}_{\mathrm{pan}}$ treatment presented the highest length $(11.1 \mathrm{~cm})$, probably because the length of the principal root was reached close to 35 DAS, period in which there were no differences in water applications. Klocker (1997) and Ebner (1995) reported similar The highest values of carrot basal diameter were found in the 75, 100 and values in length and diameter to the ones obtained in this study.

The highest values of carrot basal diameter were found in the 75, 100 and $125 \% \mathrm{E}_{\mathrm{pan}}$, treatments, being growth and development more intensive between the 95 and 113 DAS (Figure 6), which is likely to be the result of greater water application. According to Reigosa et al. (2003), diameter growth of the principal root begins close to 35 DAS, where the roots of the plants with water deficit will continue growing, especially those who have available water levels. In this study, root diameter growth presented statistical differences $(p \leq 0.05)$ that were significant at 113 and 123 DAS. In contrast, lower values were obtained with $25 \%$ and $50 \% \mathrm{E}_{\mathrm{pan}}$ treatments. This can be explained because small changes in turgidity, during the process of cell growth can reduce the cell enlargement and growth (Azcón-Bieto and Talón, 2000).

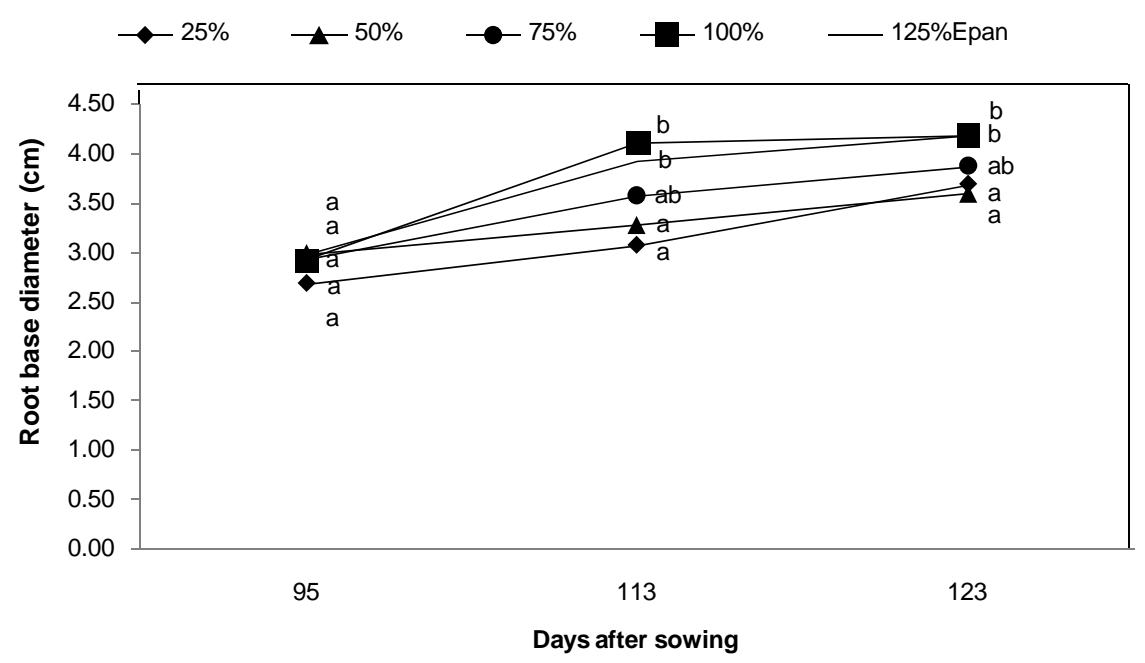

Figure 6. Root base diameter $(\mathrm{cm})$ of carrot in the different water treatments measured at 95,113 and 123 days after sowing, in a Haploxerand soil. Different letters in vertical order differ significantly, Duncan's test $(p \leq 0.05)$. 


\section{Crop water production function}

The analysis of the relationship between crop yield $(\mathrm{Y})$ in response to different levels of water input (W) showed that the highest yield was obtained in the $100 \%$ $\mathrm{E}_{\mathrm{pan}}$ treatment, with a water application of $4606 \mathrm{~m}^{3} \mathrm{ha}^{-1}$. Nevertheless, as the water application level increased from $25 \%$ to $125 \% \mathrm{E}_{\mathrm{pan}}$, it decreased the WUE (Table 1). Crop yield did not decrease and statistical differences $(p \leq 0.05)$ were not significant among treatments. These results are in agreement with Kirschbaum et al. (2004) in raspberry. They determined that WUE presents no significant differences between treatments of irrigation and that WUE decreases with the increase of applied water. In contrast, Gibberd et al. (2003) obtained a higher marketable yield in carrot with a water application level of $151 \% \mathrm{E}_{\mathrm{pan}}$ in sandy textured soils, but with a $97 \% \mathrm{E}_{\mathrm{pan}}$, WUE increased $17 \%$ and the marketable yield decreased from $73 \%$ to $63 \%$. The marginal analysis of water production function $(\Delta \mathrm{Y} / \Delta \mathrm{W})$ shows that the highest yield was obtained for the $75 \% \mathrm{E}_{\mathrm{pan}}$ treatment with a value of $19.4 \mathrm{~kg} \mathrm{~m}^{-3}$ (Table 2) that, according to Liu et al. (2002)), corresponds to the point of maximum water use efficiency; therefore, it is the recommended water level.

\section{CONCLUSIONS}

We found that the highest yield of carrot crop in a Haploxerand soil was obtained with the $100 \% \mathrm{E}_{\mathrm{pan}}$ treatment. The maximum WUE corresponded to $75 \%$ $\mathrm{E}_{\text {pan }}$ treatment, with an applied water volume of $3864 \mathrm{~m}^{3} \mathrm{ha}^{-1}$, which corresponds to the water application level recommended for drip irrigation scheduling in carrot. The decrease applied in the water volume did not affect crop yield nor quality parameters significantly. On the other hand, the excess of soil water caused a decrease in plant density and root size. The relationship between crop yield and applied water volume obtained for the carrot crop with drip irrigation will help to improve the management of the water resources for this crop under water scarcity conditions.

\section{REFERENCES}

Azcón-Bieto, J., Talón, M. 2000 Fundamentos de fisiología vegetal. McGraw-Hill Interamericana. Madrid, España, 522 p.

Behboudian, M.H., Singh, Z. 2001. Water relations and scheduling in grapevine. Hortic. Rev. 27, 189 - 225.

Carlton, B., Peterson, C. 1963. Breeding carrot for sugar and dry mater content. Proc. Amer. Soc. Hort. Sci. 82, 333-340.

Darwish, T.M., Atallah, T.W., Hajhasan, S., Haidar, A. 2006. Nitrogen and water use efficiency of fertigated processing potato. Agric. Water Manage. 85, 95-104.

Ebner, P. 1995. Efectos del nitrógeno y momento de cosecha sobre aspectos de calidad y rendimientos de zanahoria (Daucus carota L.) en la provincia de Valdivia. Tesis Ing. Agr. Valdivia, Universidad Austral de Chile, 90 p.

Evers, M., Tuuri, H., Hägg, M., Plaami, S., Häkkinen, U., Talvitie, H. 1997. Soil forming and plant density effects on carrot yield and internal quality. Plant Foods Hum. Nutr. 51, 283 $-294$

FAO (Italia). 2006. Evapotranspiración del cultivo: guía para la determinación de los requerimientos de agua de los cultivos. Estudio FAO riego y drenaje 56. FAO. Roma, Italia, 298 p.

Galeano, M., Martinez, R., Díaz, R. 2003. Evaluación del comportamiento de cuatro variedades de zanahoria (Daucus carota L.) cultivadas bajo dos sistemas de riego. Investigación Agraria. 7, 49 - 53. 
Gallardo, V. 1997. Efecto de los momento de cosecha sobre el rendimiento y producción de jugo de seis cultivares de zanahoria (Daucus carota L.) bajo las condiciones de Osorno. Tesis Ing. Agr. Valdivia, Universidad Austral de Chile, $98 \mathrm{p}$.

Giaconi, M.V., Escaff, G.M. 1993. Cultivo de hortalizas. Editorial Universitaria S.A. Octava edición. Santiago, Chile, 332 p.

Gibberd, M., Mckay, A., Calder, T., Turner, N. 2003. Limitations to carrot (Daucus carota L.) productivity when grown with reduced rates of frequent irrigation on a free-draining, sandy soil Aust. J. Agric. Res. 54, 499 - 506.

Gray, D., Benjamin, L. 1993. Controlling the size of carrot - The roles of seed quality and plant density. Acta Hortic. 354, 47 - 54.

Hassanli, A.M., Ahmadirad, S., Beecham, S. 2010. Evaluation of the influence of irrigation methods and water quality on sugar beet yield and water use efficiency. Agric. Water Manage. 97, 357-362.

Honorato, P.R. 2000. Manual de edafología Ediciones Universidad Católica de Chile. Cuarta edición. Facultad de Agronomía e Ingeniería Forestal. Santiago, Chile, 241 p.

INE. 2007. Censo Agropecuario y Forestal 2007 Resultados por Comuna. [en línea]. http://www.ine.cl/canales/chile estadistico/censo s_agropecuarios/xls comunas/9.xls

INFOSTAT. 2004. InfoStat: Software estadístico. Manual del usuario. Versión 2004. Grupo InfoStat, FCA, Universidad Nacional de Córdoba. Editorial Brujas. Córdoba, Argentina.

Kirschbaum, D.S., Correa, M., Bórquez, A.M., Larson , K.D., DeJong, T.M. 2004. Water requirements and water use efficiency of fresh and waiting bed strawberry plants.Acta Hort. 664, 347-352.

Klocker, C. 1997. Momento de cosecha de raíces y aspecto de calidad de jugo de seis cultivares de zanahoria (Daucus carota L.) bajo las condiciones de Puerto Octay. Tesis Ing. Agr. Valdivia. Universidad Austral de Chile, $92 \mathrm{p}$.

Liu, W.Z., Hunsaker, D.J., Li, Y.S., Xie, X.Q., Wall, G.W. 2002. Interrelations of yield, evapotranspiration, and water use efficiency form marginal analysis of water production functions. Agric. Water Manage. 56, 142-151.
Novoa, R. 2004. Nuevos desarrollos agronómicos para incrementar el uso eficiente del agua. Simiente. 74, 7 - 25.

Otto, R.F., Giménez, C. 2000 Evapotranspiration and dry mater production of horticultural crops under cover. Acta Hort. 516, 23-30.

Pozo, A. del, Canto, P. del 1999. Áreas agroclimáticas y sistemas productivos en la VII y VIII regiones. INIA - Quilamapu. Chillán, Chile, $116 \mathrm{p}$.

Prabhakar, M., Srinivas , K. , Hedge, D.M. 1991. Effect of irrigation regimes and nitrogen fertilization on growth, yield, $\mathrm{N}$ uptake, and water use of carrot (Daucus carota L.). Gartenbauwissenschaft. 56, 206 - 209.

Reigosa, M.J., Pedrol , N., Sánchez, A. 2003. La ecofisiología vegetal: una ciencia de síntesis. Thomson Editores. Madrid, España, 1193 p.

Richards, R., Rebetzke, G.J., Condon, A.G., Herwaarden, A.F. 2002. Breeding opportunities for increasing and crop the efficiency of water use yield in temperate cereals. Crop Sci. 42, 111121.

Sato, T., Abdalla, O.S., Oweis, T.Y. Sakuratani, T. 2006. Effect of supplemental irrigation on leaf stomatal conductance of field grown wheat in northern Syria. Agric. Water Manage. 85, 105-112.

Selles, G., Ferreyra, R. 2005. Criterios para controlar el riego en uva de mesa. En: Curso internacional: Manejo de riego y suelo en vides para vino y mesa 26 y 27 de octubre, 2005. INIA - La Platina. Ministerio de Agricultura. Santiago, Chile.

Steel, R.G.D., Torrie, J.H. 1992. Bioestadística; Principios y procedimientos. $2^{\mathrm{a}}$ edición. Mc Graw Hill. $622 \mathrm{p}$

Stolpe, N. 2006. Descripciones de los principales suelos de la VIII región de Chile. Universidad de Concepción. Chillán, Chile, 84 p.

Taylor, R.D., Grout, B.W.W., Hill, J. 2004 Use of a tensiometer -based control system to reduce irrigation of cut flower Dianthus caryophyllus 'Santorini' whilst maintaining flower yield and quality. Acta Hort. 664, 647651.

Thompson, R.B., Gallardo, M., Fernández, M.D. 2004. Irrigation scheduling of drip- 
irrigated vegetable crops grown in greenhouses using continuous soil moisture monitoring. Acta Hort. 664, 653-660.

Villeneuve, F., Leteinturier, J. 1992. L'alimentation hydrique. In: La carotte, tome 2 état des connaissances. Centre Technique Interprofessionnel des Fruits et Légumes. Paris, France, pp. 103-115.

Wan, S., Kang, Y. 2006. Effect of drip irrigation frecuency on radish (Raphanus sativus L.) growth and water use. Irrig. Sci. 24 , 161-174.

Westerveld, S.M., Mckeown, A.W. Mcdonald, M.R. 2006. Seasonal nitrogen partitioning and nitrogen uptake of carrots as affected by nitrogen application in a mineral and an organic soil. HortScience. 41, 1332 1338
Wayne,P.H. 2002. Implications of atmospheric and climate change for crop yield and water use efficiency. Crop Science. 42, 131-139.

Webber, H. A., Madramootoo, C. A., Bourgault, M., Horst, M.G., Stulina, G., Smith, D.L. 2006. Water use efficiency of common bean and green gram grown using alternate furrow and deficit irrigation. Agric. Water Manage. 86, 259- 268.

Zapata, M., Segura, P. 1995. Riego deficitario controlado: Fundamentos y aplicaciones. Ediciones Mundi Prensa, Madrid, España, 188 p.

Zegbe, J.A., Hossein, M., Clothier, B. E. 2006. Responses of 'Petopride' processing tomato to partial rootzone drying at different phenological stages. Irrig. Sci. 24, 203-210. 